\title{
Leaders
}

\section{Protein glycosylation in cancer biology: an overview}

\author{
F Dall'Olio
}

\begin{abstract}
Introduction
Glycosylation is one of the most frequentlyoccurring post-translational modifications of proteins. The presence of an oligosaccharide moiety in soluble and membrane bound proteins improves solubility in water, contributes to the proper orientation of the molecule, protects it from proteases and, in some cases, is required for efficient intracellular transport. Some oligosaccharide sequences may also mediate highly specific molecular and cellular recognition. In the first section of this review the biochemistry of protein glycosylation is summarised briefly; the second section deals with cancer related oligosaccharide changes and invasive properties of cancer cells, with special emphasis on experimental systems; the third section focuses on specific oligosaccharide structural alterations in human cancers.
\end{abstract}

\section{Biosynthesis of glycoprotein oligosaccharides}

The biosynthesis of glycoprotein oligosaccharides (for a detailed review $\operatorname{see}^{12}$ ), is catalysed by glycosyltransferases, a family of 100 or more enzymes which transfer a sugar residue from a nucleotide-sugar donor (for example, GDPfucose, UDP-galactose and CMP-sialic acid) to an acceptor which can be a sugar, an amino acid or a lipid. Glycosyltransferases are classified on the basis of the sugar they transfer (for example, fucosyltransferases, galactosyltransferases, sialyltransferases). Moreover, members of each glycosyltransferase family are distinguished on the basis of the structure they recognise as an acceptor and of the isomeric linkage they form (for example, $\alpha 2,3$ and $\alpha 2,6$ sialyltransferases catalyse the linkage of sialic acid to either the third or the sixth oxydril group of the penultimate sugar residue). The biosynthesis of a given glycosidic structure is controlled mainly at the level of expression of the cognate glycosyltransferase. Glycoprotein bound oligosaccharides fall into two well defined categories: those linked to the amidic nitrogen of asparagine ( $N$-linked) and those linked to oxydril side group of serine or threonine (O-linked).

\section{Dipartimento di \\ Patologia \\ Sperimentale, Università di Bologna, \\ Via S. Giacomo, 14} 40126 Bologna, Italy

Accepted for publication 3 October 1995
BIOSYNTHESIS OF N-LINKED CHAINS

This process occurs through several discrete steps (fig 1). In the rough endoplasmic reticu- lum (RER) an oligosaccharide comprised of two $N$-acetylglucosamine (GlcNAc), nine mannose and three glucose residues is synthesised on a lipid carrier, the dolichol-phosphate, by the sequential action of the corresponding glycosyltransferases (fig 1A). This oligosaccharide is then transferred en bloc to an asparagine residue of the nascent polypeptide chain by the action of a multienzymatic complex, the oligosaccharyltransferase. Oligosaccharides containing five or more mannose residues are referred to as "high-mannose types". After the transfer to protein the three glucose residues and four of the nine mannose residues are "trimmed" by specific glycosidases. The "trimmed" oligosaccharides, comprising five mannose and two GlcNAc residues (fig 1B), may then act as acceptors for GlcNAc transferase I, located in the Golgi apparatus (fig 1C). The addition of the first GlcNAc residue represents the first event of the conversion of the oligosaccharide from the "highmannose" to the "complex type"; two other mannose residues are subsequently removed by Golgi mannosidase II and other GlcNAc and galactose residues are added (fig 1D). The resulting branched structure may be elongated by the sequential addition of galactose, fucose and sialic acid. A typical tetra-branched, fully sialylated "complex type" glycan is shown in fig 1E. These structures are comprised of an invariant "core" portion containing three mannose and two GlcNAc residues and two to five antennae.

BIOSYNTHESIS OF O-LINKED CHAINS

$\mathrm{N}$-acetylgalactosamine (GalNAc) is the first sugar residue to be linked to serine or threonine. Without further elongation, this structure forms the Tn antigen (fig 2). Elongation with galactose linked to the $O-3$ position creates the core 1 structure, while the presence of GlcNAc linked $\beta 1,6-$ or $\beta 1,3-$ to GalNAc forms core 2 and 3 structures, respectively (fig 2). These three structures are often further elongated by the addition of other galactose, GlcNAc and GalNAc residues, and terminated by fucose or sialic acid, or both. The unsubstituted core 1 structure represents the Thomsen-Friedenreich (or T) epitope. Substitution of the first GalNAc in the $O-6$ position with sialic acid creates the sialyl-Tn antigen, which does not undergo further elongation. It is gen- 
erally agreed that the first step of $O$-glycosylation occurs in cis Golgi, while the addition of other sugars takes place in more distal compartments.

\section{Aberrant glycosylation in cancer cells}

Generally, the most frequently described cancer related changes in the pattern of glycosylation include the synthesis of highly branched and heavily sialylated glycans, ${ }^{3}$ the premature termination of biosynthesis, resulting in the expression of uncompleted forms, and the re-expression of glycosidic antigens of fetal type. ${ }^{4}$ In many cases the formation of these aberrant structures depends on altered regulation of one or more key glycosyltransferases; the molecular basis of this phenomenon remains obscure in other cases. ${ }^{5}$ In experimental systems the relation between altered glycosylation and cancer biology has been studied using one of two approaches: the first involves the modification of the glycosylation pattern of cancer cell membranes by means of glycosylation inhibitors or glycosidase treatments; the second is based on the study of subpopulations of cancer cells selected for a given phenotypefor instance, increased or reduced metastatic ability or resistance to a given lectin.

\section{MODIFICATION OF GLYCOSYLATION PATTERN}

There are several inhibitors of specific steps of $N$-linked biosynthesis. Tunicamycin blocks the first step of $N$-glycosylation, giving rise to the production of proteins devoid of $N$-linked chains. Castanospermine inhibits glucosidase I, the first "trimming" enzyme, causing the formation of glycoproteins bearing high mannose $N$-linked chains terminating with glucose (fig 1A). Swainsonine is an inhibitor of Golgi mannosidase II, the last "trimming" enzyme and induces the formation of "hybrid type" glycans, similar to the structure shown in fig $1 \mathrm{C}$, comprised of five mannose residues and one complex type antenna, usually formed by GlcNac, galactose and sialic acid. Treatment of B16 murine melanoma cells with tunicamycin, castanospermine or swainsonine results in a dramatic reduction in the number of pulmonary metastases in syngeneic mice and in reduced retention of drug treated cells in the target organ. ${ }^{6-8}$ Consistent results have been obtained with L-1 mouse sarcoma cells. ${ }^{9}$ In mouse mammary tumour cells, however, tumour and metastasis formation was inhibited on treatment with tunicamycin, but not with swainsonine. ${ }^{10}$ Swainsonine inhibits the growth of human cell lines in vivo at the site of inoculation $^{11}{ }^{12}$ and metastasis formation, ${ }^{13}{ }^{14}$ even when administered to host animals systemically. Two mechanisms have been proposed to explain such effects. First, combination treatment with swainsonine and interferon- $\alpha 2$ enhances the activity of the interferon inducible enzyme 2'5'-oligoadenylate synthetase, suggesting that swainsonine may potentiate the antiproliferative effect of interferon. ${ }^{11}{ }^{15} \mathrm{Sec}-$ ond, treatment with swainsonine increases natural killer (NK) cell activity of host animals two to threefold and swainsonine dependent reduction in metastasis formation is not observed in NK cell depleted animals. ${ }^{13}$ Swainsonine is currently under consideration as an antineoplastic agent in a phase I clinical study. ${ }^{16}$ The sialyltransferase specific inhibitor KI-8110 has facilitated the investigation of the role of sialic acid in the regulation of the metastatic cascade. Because of its negative electric charge and as it is frequently present at the terminal non-reducing end of glycoprotein oligosaccharides, sialic acid has long been suspected of playing a key role in mediating biological recognition events, including those responsible for invasive tumour growth. Treatment of murine ${ }^{17}$ and human ${ }^{18}$ colon cancer cell lines with $\mathrm{KI}-8110$ results in a significant reduction in sialic acid on the cell surface and in a dramatic reduction in lung and liver metastasis formation. Enzymatic removal of sialic acid increases binding of collagen type IV and fibronectin by highly metastatic cell lines. ${ }^{19}$ Treatment with KI-8110, however, does not affect adhesion to these substrates, but decreases the ability of tumour cells to induce platelet aggregation. ${ }^{20}$ This suggests that sialic acid may exert its effect on metastasis formation by controlling the formation of aggregates of tumour cells and platelets.

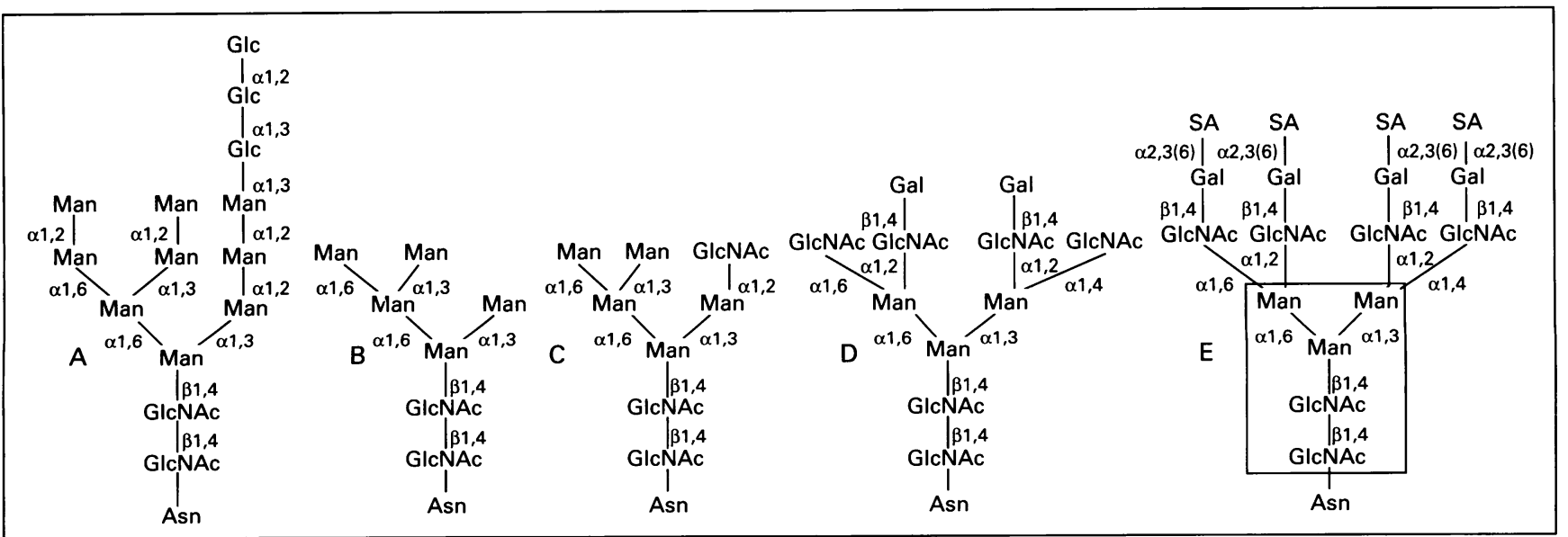

Figure 1 Simplified representation of the N-linked chain biosynthetic pathway. See text for details. Glc = glucose; Man = mannose; Gal = galactose; GlcNAc $=N$-acetylglucosamine; $S A=$ sialic acid. Glycans containing five to nine mannose residues (structures $A-C$ ), may also be retained by mature glycoproteins. The number of branches (antennae) in complex glycans usually ranges from 2 to 4 . Sialic acid may be linked to galactose either via $\alpha 2,3-$ or $\alpha 2,6$-linkages. The number of sialic acid residues usually ranges between 0 and 4 (structure E). The core pentasaccharide is boxed in $E$ 
USE OF SELECTED MUTANTS

Many authors have studied subpopulations of cells selected for resistance to wheat germ agglutinin (WGA), a lectin with a broad specificity for sialic acid, terminal GlcNAc and poly- $\mathrm{N}$-acetyllactosaminic units (that is, repeating Gal $\beta 1,4 \mathrm{GlcNAc}$ units). ${ }^{21}$ In 1977 , Tao and Burger ${ }^{22}$ reported the isolation of WGA resistant clones of mouse melanoma cells displaying a dramatic reduction in metastatic ability. In 1981, Yogeeswaran and $\mathrm{Salk}^{23}$ reported that the ability of murine tumour cells to metastasise spontaneously from subcutaneous sites of injection was positively correlated with substitution of GalNAc and galactose by sialic acid (that is, the larger the number of GalNAc and galactose residues "covered" by sialic acid, the greater the number of metastatic cells). Studies on WGA resistant variants and revertants of the murine melanoma cell line MDAY-D2 indicate that reduced expression of surface sialic acid is associated with a poorly metastatic phenotype and increased binding to collagen type IV and fibronectin. ${ }^{24}{ }^{25}$ The mutant WGA resistant cells lack large, sialic acid bearing $N$-linked glycans, with poly $\mathrm{N}$-acetyllactosaminic units (normally present in parent WGA sensitive cells) and accumulate truncated glycans. ${ }^{26}{ }^{27}$ The relation between WGA resistance and reduced metastatic ability has been confirmed for different human and murine cancer cell lines. ${ }^{28-31}$ Moreover, the ability of $\mathrm{T}$ cell hybridoma clones to invade primary cultures of hepatocytes and to metastasise in syngeneic mice is positively correlated with reduced binding of lectins specific for penultimate sugar residues, which indicates a high degree of sialic acid substitution. ${ }^{32}$ However, other reports suggest that this relation may be less direct. Subpopulations of colon cancer cells expressing a more aggressive phenotype bear a higher number of cell surface sialic acid residues but this results in increased rather than decreased binding to collagen type IV and fibronectin. ${ }^{33}$ Other investigators failed to detect any difference in the amount of sialic acid released by clones of the B16 murine melanoma cell line with differing metastatic potentials. Rather, they found a correlation between metastatic potential and the number of terminal galactose residues. ${ }^{34}{ }^{35}$ The involve-

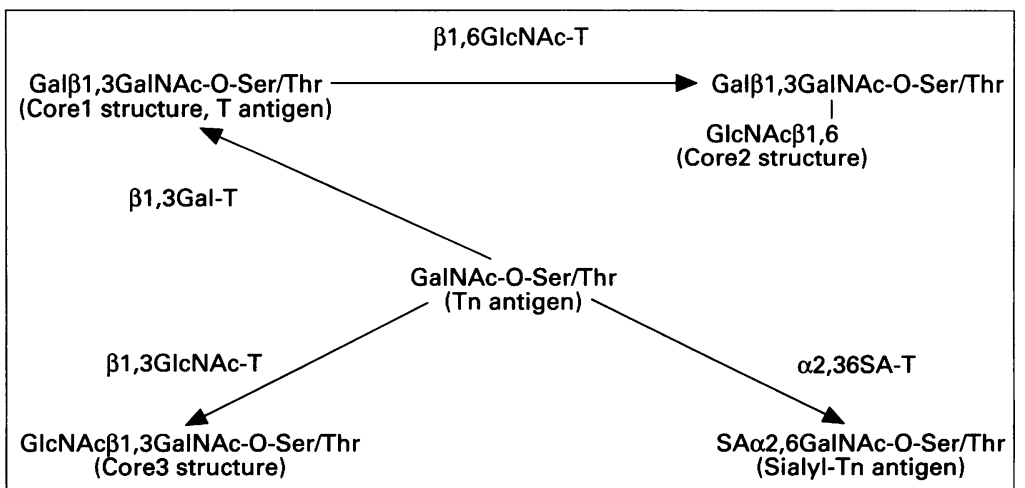

Figure 2 Commonly occurring biosynthetic pathways of O-linked chain biosynthesis. Abbreviations as in fig 1; GalNAc $=N$-acetylgalactosamine; $\beta 1,3 \mathrm{gal}-T=$

$\beta 1,3-$ galactosyltransferase (Gal to GalNAc); $\beta 1,6 G l c N A c-T=\beta 1,6-N$-acetylglucosaminyltransferase (GlcNAc to GalNAc); $\beta 1,3 G l c N A c-T=\beta 1,3-N$-acetylglucosaminyltransferase (GlcNAc to GalNAc); $\alpha 2,6 S A-T=\alpha 2,6$-sialyltransferase (SA to GalNAc). ment of terminal galactose residues in the metastatic cascade is supported, firstly, by the observation that in vitro binding of a glycosylation mutant of the lymphoreticular cell line MDAY-D2, lacking terminal sialic acid and galactosyl residues, to endothelial cells on galactosylation is increased by exogenous galactosyltransferase ${ }^{36}$; and, secondly, that the capacity of adrenal carcinoma cells to invade a reconstituted basement membrane in vitro is correlated with the level of galactosylation of cell surface glycoproteins catalysed by a cell surface galactosyltransferase. ${ }^{37}$

Although sometimes conflicting, the data outlined here indicate that the absence of or a reduction in the number of fully processed, sialic acid-bearing $N$-linked glycans reduces the invasiveness of cancer cells, probably by altering their adhesion properties or by increasing their susceptibility to the host's immune system. However, on the one hand, it should be remembered that some inhibitors of glycosylation are cytotoxic, that their effect is reversible and is not specific for particular oligosaccharide structures. On the other hand, cells selected for a given phenotype may differ from the original cell population, not only for the chosen phenotype but also for many other properties. Thus, any causal relation between altered glycosylation and the phenotype of cancer cells should be considered with great care.

\section{Oligosaccharide structures specifically involved in cancer biology}

Changes in the following oligosaccharide structures have often been associated with human cancer and are important because: (1) they may be related to a precise stage of the disease and their detection with lectins or monoclonal antibodies may provide useful diagnostic or prognostic information, or both; and (2) in many cases they contribute directly to cancer biology.

\section{POLYSIALIC ACID}

Polysialic acid (PSA) is a linear polymer formed by sialic acid residues usually linked through $\alpha 2,8$ bonds. This is the only known instance where sialic acid occurs as an internal sugar. In mammals PSA occurs virtually only on $N$-linked chains of the neural cell adhesion molecule (N-CAM) and on the $\alpha$ subunit of sodium channels in the brain. Its pattern of expression is developmentally regulated: the number of sialic acid residues arranged as PSA on N-CAM is around 10 in fetal rat brain and around two to three in the adult. ${ }^{38}$ The maturation dependent shift from the expression of the high to the low PSA bearing form of $\mathrm{N}-\mathrm{CAM}$ plays a pivotal role in controlling the strength of cell-cell and cell-matrix interactions. ${ }^{39}{ }^{40}$ High PSA bearing N-CAM is expressed by several human fetal tissues and re-expressed by the corresponding neoplasms. Indeed, its presence has been reported in malignant tumours of neuroectodermal origin, such as medulloblastomas and neuroblastomas, ${ }^{41}$ and in neuroblastoma cell lines, ${ }^{42}{ }^{43}$ but not in ependymomas and gliomas. ${ }^{41}$ Remark- 
ably, polysialic acid chains longer than 55 residues have been described in CHP-134 neuroblastoma cells. ${ }^{43}$ It should be emphasised that the presence of the long chains of PSA may have an enormous effect on the strength of homophilic binding between N-CAM molecules on different cells. High PSA is expressed by small cell lung carcinoma (SCLC), ${ }^{42}$ a cancer of neuroendocrine origin with a very poor prognosis, but not by carcinoids or other lung tumours. High PSA expression in SCLC correlates with reduced cell-cell adherence, greater clonogenic ability in semisolid media and a significantly higher metastatic ability in nude mice. ${ }^{45}$ Among thyroid tumours, high PSA is expressed by medullary carcinomas and has been proposed as a useful marker to distinguish medullary carcinomas from other thyroid tumours. ${ }^{46}$ The presence of high PSA in the mesodermally derived Wilms tumour ${ }^{47}$ indicates that the expression of these structures is not restricted to tissues of neuroectodermal origin.

SIALIC ACID $\alpha 2,6$-LINKED TO GALACTOSE

In about $90 \%$ of colon cancer specimens the activity of the enzyme catalysing the addition of sialic acid in $\alpha 2,6$-linkage to galactose residues of $N$-linked chains $(\alpha 2,6 \mathrm{ST})$ is increased. ${ }^{48}$ This results in augmented binding of the Sambucus nigra lectin (SNA), specific for $\alpha 2,6$-linked sialic acid, to histological sections of the vast majority of grade I and II colon carcinomas $^{49}{ }^{50}$; the few cases of grade III carcinoma examined were poorly or non-reactive. ${ }^{50}$ Among benign lesions, strong SNA reactivity is expressed only by polyps with severe dysplasia. ${ }^{49}{ }^{50} \mathrm{~A}$ very similar pattern of expression was observed in an histochemical study utilising the lectin from Trichosanthes japonica, specific for sialic acid $\alpha 2,6$-linked to Gal $\beta 1,4 \mathrm{GlcNAc}{ }^{51}$ These data, together with the differentiation dependent expression of $\alpha 2,6 \mathrm{ST}$ shown by rat $^{5253}$ and human ${ }^{54}$ intestinal cells, suggest that a high level of $\alpha 2,6$-sialylation in the colonic cell is restricted to a specific degree of tissue differentiation. Enhanced $\alpha 2,6$-sialylation of galactose in colon cancer has also been found to be associated with glycolipids. ${ }^{55}$ In fibroblasts transfection with activated ras oncogenes results in the enhancement of $\alpha 2,6 \mathrm{ST}$ activity and mRNA expression, ${ }^{57} 58$ and in an increased invasive potential. ${ }^{59} \mathrm{~A}$ role for this modification in colon cancer progression is suggested by several observations. Metastatic specimens of colorectal cancer express an $\alpha 2,6 \mathrm{ST}$ at even higher levels than primary tumours. ${ }^{60}$ Subpopulations of the adherent colon carcinoma cell line SW948, which is devoid of $\alpha 2,6 \mathrm{ST}$ activity, selected for their ability to grow in non-adherent conditions, express high levels of $\alpha 2,6 \mathrm{ST}$ activity ${ }^{61}$ suggesting that this sialyllinkage contributes to reduced colon cancer cell adhesion. Murine colon cancer cell lines selected for the ability to metastasise in the liver after caecal injection, express two to three times more SNA binding proteins than the poorly metastatic parental cell line. ${ }^{62}$ Variants of the murine colon cancer cell line MCA-38 with high liver colonising potential express an $\alpha 2,6 S T$ mRNA level about fourfold higher than low liver colonising variants. ${ }^{63}$ Human colon cancer cell lines grown as xenografts in nude mice and the xenograft derived cell lines expressed an $\alpha 2,6 \mathrm{ST}$ activity significantly higher than that of the parental cell line. ${ }^{64} \mathrm{By}$ contrast, a mutant of the murine melanoma cell line MDAY-D2, with increased $\alpha 2,6 \mathrm{ST}$ activity, has a reduced metastatic ability. ${ }^{65}$ The recent establishment of a panel of human colon cancer cell lines differing only in their level of $\alpha 2,6 \mathrm{ST}$ expression, obtained by transfection with $\alpha 2,6 \mathrm{ST}$ cDNA, should provide more direct information on the role of $\alpha 2,6$-linked sialic acid in colon cancer progression. ${ }^{66}$

\section{B1-6 BRANCHING}

One of the most important cancer related changes is increased $\beta 1,6$ branching of $N$-linked chains. This modification involves the presence of an antenna whose first GlcNAc residue is $\beta 1,6$-linked to a core mannose residue (fig 1D) and has been directly associated with metastatic potential. Transfection of NIH 3T3 cells with DNA from neuroblastoma and bladder carcinoma cell lines containing activated ras oncogenes results in enlarged glycoprotein oligosaccharides, detected by a shift in the gel filtration profile. ${ }^{67}{ }^{68}$ Glycans from transfected cells showed an increased affinity to leukoagglutinin (L-PHA), a lectin specific for $N$-linked chains containing a $\beta 1,6$-linked antenna. ${ }^{67}$ This modification may also be caused by transformation with both $\mathrm{DNA}^{69}$ and $\mathrm{RNA}^{70}$ tumour viruses and by transfection with the $\mathrm{v}$-fps/fes oncogene, which encodes a cytoplasmic tyrosine kinase, ${ }^{71}$ but not by transfection with the nuclear oncogene myc. ${ }^{71} \mathrm{~A}$ direct association between increased $\beta 1,6-$ branching and metastatic potential is suggested by several studies. Mutants of MDAY-D2 cells selected for L-PHA resistance display a tumorigenic potential similar to that of the parental cells, but their metastatic potential is dramatically reduced. ${ }^{72}$ The activity of GlcNAc transferase $V$, the enzyme responsible for $\beta 1,6$ branching, is reduced, as is binding of L-PHA to 130 kilodalton glycoproteins. Transfection of the tumorigenic, non-metastatic mammary adenocarcinoma cell line SP1 with activated T24H-ras, but not with non-activated c-H-ras, results in the expression of the metastatic phenotype and a concomitant increase in binding of L-PHA to 130 kilodalton glycoproteins. ${ }^{72}$ L-PHA reactive oligosaccharides are preferentially expressed by the lysosomal associated membrane glycoprotein 1 (LAMP-1), a glycoprotein found largely in lysosomal membranes and also in the plasma membrane. ${ }^{73}{ }^{74}$ It has been suggested that the presence of $\beta 1-6$ branched $N$-linked chains facilitates the invasion of basement membranes. ${ }^{75}$ Clinical studies revealed an increased level of L-PHA reactivity in tissue sections of human cancers. In oesophageal carcinomas L-PHA positive cells are distributed predominantly on the outer surface of the tumour, adjacent to the surrounding tissue. $^{76}$ All breast carcinomas and epithelial hyperplasia with atypia showed increased staining for L-PHA compared with fibroad- 
enomas and hyperplasia without atypia. ${ }^{77}$ In $O$-linked chains the presence of a $\beta 1,6$-linked GlcNAc residue (in this case to the peptide linked GalNAc; core 2 structure) has also been associated with metastatic behaviour and the activity of the enzyme catalysing this reaction (core $2 \beta 1,6 \mathrm{GlcNAc}$ transferase) is raised in metastatic murine tumour cell lines, ${ }^{78}$ and also in human acute myeloblastic and chronic myelogenous leukaemia cells. ${ }^{79} O$-linked glycans containing core 2 structures are present, linked to the major glycoprotein leukosialin, on the surface of activated $\mathrm{T}$ lymphocytes and in acute $\mathrm{T}$ lymphocytic leukaemia cells. ${ }^{80}{ }^{81} \mathrm{By}$ contrast, in human colon core $2 \beta 1,6$ GlcNAc transferase activity decreases during progression to cancer. ${ }^{82} 83$

LACTO SERIES CHAINS

As shown in fig 3, galactose may be linked to GlcNAc either through a $\beta 1,3$ or through a $\beta 1,4$ linkage, forming the two basic units for linear type 1 and type 2 lacto series chains, respectively. Repetition of the two basic units form the extended lacto series chains, frequently found in $\mathrm{N}$ - and $\mathrm{O}$-linked glycans of glycoproteins and in glycolipids. When extended type 2 chains, which are referred to as polylactosaminic, are linearly arranged, the " $i$ " antigen is formed. The presence of a GlcNAc $\beta 1,6$-linked to galactose provides a branching point which, with further elongation, forms the

\begin{tabular}{|c|c|}
\hline Basic unit of type 1 chain & Gal $\beta 1,3 \mathrm{GIcNAc}$ \\
\hline Basic unit of type 2 chain & Gal $\beta 1,4 \mathrm{GlcNAc}$ \\
\hline i antigen & $(\mathrm{Gal} \beta 1,4 \mathrm{GlcNAc} \beta 1,3 \mathrm{Gal} \beta 1,4 \mathrm{GlcNAc})_{n}-\mathrm{R}$ \\
\hline I antigen & GlcNAc $\beta 1,3 \mathrm{Gal} \beta 1,4 \mathrm{GlcNAc}-\mathrm{R}$ \\
\hline & Gal $\beta 1,4$ GlcNAc $\beta 1,6$ \\
\hline $\mathrm{H}$ antigen & $\begin{array}{l}\text { Gal } \beta 1,3(4) \text { GIcNAc-R } \\
\text { Fuc } \alpha 1,2\end{array}$ \\
\hline$A$ antigen & $\begin{array}{c}\text { GalNAc } \alpha 1,3 \text { Gal } \beta 1,3(4) \text { GIcNAc-R } \\
\text { Fuc } \alpha 1,2\end{array}$ \\
\hline$B$ antigen & $\begin{array}{l}\text { Gal } \alpha 1,3 \text { Gal } \beta 1,3(4) \text { GIcNAc-R } \\
\text { Fuc } \alpha 1,2\end{array}$ \\
\hline Lewis $^{\mathrm{a}}$ antigen & $\begin{array}{c}\text { Gal } \beta 1,3 \mathrm{G} \mid \mathrm{cNAc}-\mathrm{R} \\
\text { Fuc } \alpha 1,4\end{array}$ \\
\hline Lewis $^{b}$ antigen & Gal $\beta 1,3 G \mid c N A c-R$ \\
\hline Lewis ${ }^{x}$ antigen & $\begin{array}{c}\text { Gal } \beta 1,4 \text { GIcNAc-R } \\
\text { Fuc } \alpha 1,3\end{array}$ \\
\hline Lewis ${ }^{y}$ antigen & GalB1,4GIcNAc-R \\
\hline & Fuc $\alpha 1,2$ Fuc $\alpha 1,3$ \\
\hline Sialyl dimeric Lewis ${ }^{x}$ & \begin{tabular}{rl|}
$\mathrm{SA} \alpha 2,3 \mathrm{Ga}|\beta 1,4 \mathrm{GICNAc} \beta 1,3 \mathrm{Ga}| \beta 1,4 \mathrm{GICNAC}-\mathrm{R}$ & $\mid$ \\
Fuc $\alpha 1,3$ & Fuc $\alpha 1,3$
\end{tabular} \\
\hline
\end{tabular}

Figure 3 Structure of type 1 and type 2 derived glycosidic antigens. In Lewis antigens the presence of a sialic acid residue linked to galactose generates the corresponding sialyl-Le antigens.
"I" antigen (fig 3). The key enzymes controlling the elongation (the $i$ antigen) or branching (the I antigen) of the polylactosaminic chain are a $\beta 1,3 \mathrm{GlcNAc}$ transferase and a $\beta 1,6 \mathrm{GlcNAc}$ transferase, respectively. ${ }^{84-87} \mathrm{Sev}-$ eral observations indicate that expression of the $\mathrm{Ii}$ antigens is regulated onco-developmentally. Human fetal erythrocytes express the i antigen, whereas after birth, biosynthesis shifts toward production of the I antigen. ${ }^{87}$ Alterations in Ii antigen expression have been reported in pancreatic and lung cancers, ${ }^{88} 89$ while a reduction in overall polylactosaminoglycan expression occurs on differentiation of promyelocytic leukaemic cells (HL-60) ${ }^{90}$ and human colon cancer cells $(\mathrm{CaCo}-2){ }^{91}$ Extended lacto series chains are important not only because they are cancer related antigens but also because they provide the backbone structure for fucosyl substitutions, which give rise to $\mathrm{ABH}$ and Lewis antigens, and for sialyl substitutions (fig 3) (see later). In both $\mathrm{N}$ - and $O$-linked chains polylactosaminic sequences are mounted preferentially on $\beta 1,6$-linked GlcNAc residues ${ }^{70}{ }^{78}$; ; therefore, the expression of polylactosaminic chains seems to be controlled by the degree of $\beta 1,6$-branching.

\section{ABH HISTO-BLOOD GROUP ANTIGENS}

$\mathrm{ABH}$ antigens are carried by both glycoproteins and glycolipids on red blood cells, endo thelial and epithelial cells of many tissues and secretions. Detailed descriptions of the cancer related alterations of these histo-blood group antigens have been published previously. ${ }^{92-96}$ Aberrant expression of $\mathrm{ABH}$ antigens in tumours encompasses the following: (1) deletion of an antigen normally present in the corresponding adult tissue, with concomitant accumulation of the precursor sugar chain; (2) re-expression of fetal antigens normally absent in adult tissue; and (3) "incompatible" antigen expression which means-for example, that an individual expressing the $\mathrm{B}$ or $\mathrm{O}$ phenotype on erythrocytes may carry the $A$ antigen on colon cancer cells. Whereas the first and second modifications may be generated simply by deregulated expression of one or more of the glycosyltransferases involved in the biosynthesis of the antigen, the third requires a more complex explanation. Indeed, A and B alleles are expressed codominantly and the allele encoding A GalNAc transferase is not present in $\mathrm{B}$ or $\mathrm{O}$ individuals. The genetic and biochemical basis of this phenomenon is largely unknown. However, it should be remembered that the $A$ and $B$ transferases differ only by four amino acid substitutions ${ }^{97}$ and that under some circumstances the $B$ galactosyltransferase may also transfer GalNAc. ${ }^{98}$ Screening of gastric cancer specimens from blood group $\mathrm{O}$ individuals with a monoclonal antibody directed against A-transferase revealed the presence, in $10 \%$ of the cases, of the transferase molecule and the corresponding enzyme activity. ${ }^{99} \mathrm{ABH}$ antigens are expressed by fetal human colon according to the individual's blood type. After birth, the expression of $A, B$ and $H$ becomes restricted to the proximal colon. ${ }^{100}$ In colon cancer this 
proximal-distal gradient of expression is lost because of enhanced distal expression of these antigens. ${ }^{100}$ Other examples of aberrant expression of $\mathrm{ABH}$ antigens have been reported in pancreatic cancer, ${ }^{101}$ hepatocellular carcinoma, ${ }^{102}$ bladder and oral carcinoma, ${ }^{103} 104$ and ovarian cancer. ${ }^{105}$ In lung cancer the loss of $\mathrm{ABH}$ antigens has been positively correlated with metastatic potential and consequently with adverse prognosis. ${ }^{106}$ However, this relation was not confirmed in another study. ${ }^{107}$

\section{LEWIS ANTIGENS}

As shown in fig 3, Lewis antigens are originated by the mono- or di-fucosyl substitution of type 1 or type 2 chains. Termination of the sugar chain with sialic acid forms the corresponding sialyl-Lewis antigen. Aberrant expression of Lewis-type antigens has been reported for many cancers, including those of the lung, ${ }^{108}$ colon, ${ }^{109110}$ stomach, ${ }^{111}$ and kidney. ${ }^{112}$ These antigens are frequently shed into the blood stream. ${ }^{113}$ Sialyl-Le ${ }^{a}$, detected by monoclonal antibody N19-9, is a useful marker of pancreatic cancer. ${ }^{114}$ The interest in the expression of Lewis antigens in cancer increased enormously after the discovery that sialyl-Le ${ }^{\mathrm{x}}$ acts as a ligand for E-selectin (previously known as ELAM-1), a lectin-like cell adhesion molecule expressed on activated endothelial cells. ${ }^{115} 116$ Recently, Bergh et al reported that the closely related sialyl-Le antigen is also a ligand for E-selectin. ${ }^{117}$ Moreover, sialyl-Le ${ }^{x}$ may also be recognised by selectins $P$ and $L$, two other members of the selectin superfamily. ${ }^{118} \mathrm{E}$-selectin, the physiological role of which is to mediate leucocyte extravasation at sites of tissue damage or injury, may regulate a key event in metastasis formation, causing the arrest of cancer cells expressing the appropriate ligand (that is, sialyl-Le ${ }^{\mathrm{x}}$ ) on endothelial cells. Many observations indicate that sialyl$\mathrm{Le}^{\mathrm{x}} /$ sialyl-Le $\mathrm{a}^{\mathrm{a}}-\mathrm{E}$ selectin interactions contribute fundamentally to the adhesion of cancer cells to endothelium. ${ }^{119-122} \mathrm{~A}$ study carried out on panels of leukaemia and epithelial cancer cell lines reported that all cell lines of epithelial origin can adhere to vascular endothelium through E-selectin mediated interactions. Adhesion of cells of colonic and pancreatic origin depended mainly on sialyl-Le ${ }^{a}$. In those originating in the lung and liver sialyl-Lex contributed significantly to adhesion. Only three of 12 leukaemia cell lines showed E-selectin mediated adhesion to endothelial cells, exclusively through sialyl-Le ${ }^{\mathrm{x}}{ }^{121}$ The importance of sialyl-Le $/ \mathrm{sialyl}^{\mathrm{L}} \mathrm{Le}^{\mathrm{a}}$ antigens in the regulation of the metastatic cascade has been confirmed in clinical studies. In a study on colorectal cancer, expression of both antigens was higher in metastatic lesions than in the primary tumours. ${ }^{123}$ In non-small cell lung cancer, expression of the sialyl-Le $e^{x}$ antigen correlates with a shorter disease-free survival, ${ }^{124}$ while postoperative survival was shorter in patients with tumours expressing both sialyl- $\mathrm{Le}^{\mathrm{a}}$ and $\mathrm{Le}^{\mathrm{x}}$ antigens and $\mathrm{Le}^{\mathrm{y}} .{ }^{125}$ In melanomas sialyl-Le ${ }^{\mathrm{a}}$ expression is correlated with tumour progression. ${ }^{126}$ Sialyl dimeric $\mathrm{Le}^{\mathrm{x}}$, an antigenic variant defined by monoclonal antibody FH6, is generated by di-fucosyl substitution of an extended type 2 chain (fig 3 ) and seems to be involved in cancer progression. Expression of this antigen is restricted to poorly differentiated areas in primary colonic tumours ${ }^{127}$ and enhanced in liver metastases. ${ }^{128}$ Colon cancer cells selected for high or low sialyl dimeric $\mathrm{Le}^{\mathrm{x}}$ antigen expression display a concomitant high or low ability to invade in vitro reconstituted membranes. ${ }^{129}$ A direct correlation between sialyl dimeric $\mathrm{Le}^{\mathrm{x}}$ expression and lymph node metastasis formation has been described for transitional cell carcinoma of the human urinary bladder. ${ }^{130}$

\section{$T$, TN AND SIALYL-TN ANTIGENS}

This group of antigens, whose structure is shown in fig 2, represents truncated forms of $O$-linked chains, which can be detected by monoclonal antibodies or lectins (Arachis hypogea, PNA for T antigen; Vicia villosa, VVA or Helix pomatia, HPA for Tn antigen). In normal tissues these antigens are often present in a "cryptic" form-that is: (1) they are masked by the presence of more distal sugar residues, mainly sialic acid; and (2) they are hidden by nearby elaborate glycan structures. In normal human urothelium-for example, the $T$ antigen is substituted with sialic acid (sialy- $T$ antigen) and is not readily detectable, ${ }^{96}{ }^{131-133}$ unless the samples are treated with sialidase. Pelvic lymph node metastases were detected only in patients whose primary bladder carcinoma was T-antigen positive. ${ }^{133}$ In a percentage of bladder tumours the expression of $\mathrm{T}$ antigen is increased and has been correlated, in non-invasive tumours, with subsequent invasion. ${ }^{134}$ Other investigators proposed the combined use of $T$ and $T n$ antigens for estimating the degree of malignancy of bladder carcinoma. ${ }^{135}$ Expression of the Tn epitope, as detected with HPA, is a functional predictor of aggressiveness in breast carcinoma. ${ }^{136-138}$ Colonic tumours are probably the best studied model of $T$ and $T n$ related antigen expression. Practically, none of these antigens is expressed in normal adult epithelium. $T$ and Tn antigens are weakly expressed by hyperplastic polyps, while $\mathrm{T}, \mathrm{Tn}$ and sialyl-Tn are expressed by adenomatous polyps and carcinomas. ${ }^{95^{127}}$ 139-142 $^{\text {The biochemical basis of }}$ aberrant expression of these antigens in colon cancer is complex and incompletely understood-for example, the activity of $\alpha 2,6$ sialyltransferase synthesising the sialyl-Tn antigen seems to be decreased rather than increased in tumour tissues. ${ }^{143}$ The reduction in core 3 GlcNAc transferase activity, which normally competes with core 1 galactosyltransferase, reported in colon cancer tissues ${ }^{83}$ and cell lines, ${ }^{82}$ may contribute to the increased expression of $T$ antigen. Of the three mucin associated antigens, sialyl-Tn seems to be the most reliable tumour marker. Indeed, it is rarely expressed by hyperplastic polyps but in adenomas it is preferentially expressed by the larger and more dysplastic lesions. ${ }^{95}$ In colorectal cancer sialyl-Tn is expressed by $87 \%$ of cases, regardless of age, gender, location, Dukes' stage, degree of differentiation, and 
ploidy. Five year survival is $100 \%$ for sialyl-Tn negative compared with $73 \%$ for sialyl-Tn positive patients. ${ }^{144}$ Expression of sialyl-Tn has been proposed, together with tumour ploidy, as the most important variant for predicting disease-free and overall survival. ${ }^{144}$ Sialyl-Tn expression is a marker of malignancy and is associated with a poor prognosis in many cancers, ${ }^{145}$ including those of the pancreas, ${ }^{88} 146-148$ stomach and oesophagus, ${ }^{148-150}$ ovary, ${ }^{151}$ breast, ${ }^{152}$ and endometrium. ${ }^{153}$ In Borrmann type IV gastric carcinoma, sialyl-Tn expression correlates with lymph node and peritoneal dissemination and with a higher proliferative activity, as measured by argyrophilic nuclear organiser region (AgNOR) counts. ${ }^{154}$ Recent reports indicate that reactivity of normal colon cancer sections with the sialyl-Tn specific monoclonal antibody TKH 2 may be increased up to the levels characteristic of cancer samples by treatments which release $O$-acetyl groups from sialic acid. ${ }^{155156}$ As $O$-acetylation is a modification of sialic acid that occurs more frequently in normal than in cancerous colon, it is possible that the different reactivities observed with TKH 2 antibody reflect the loss of $O$-acetyl substituents by sialic acid rather than an accumulation of the disaccharide. This mechanism does not seem to be operating in cancers of the stomach and pancreas. ${ }^{155}$ The possibility that mucins carrying the sialyl-Tn epitope play an important role in cancer biology is indicated by the observation that NK cell mediated lysis of conventional target K562 cells may be inhibited by ovine submaxillary mucin (OSM), a mucin bearing the sialyl-Tn antigen. ${ }^{157}$ The close association between $\mathrm{Tn}$ and sialyl-Tn antigens and neoplastic transformation prompted some investigators to use such antigens for active immunotherapy. Mice immunised with desialylated OSM (that is, carrying the Tn antigen) were protected when challenged with highly invasive $\mathrm{Tn}$ antigen expressing, syngeneic mammary tumour cells. ${ }^{158}$ Studies carried out on humans indicate that treatment with a vaccine consisting of partially desialylated OSM or of sialyl-Tn disaccharide chemically linked to keyhole limpet haemocyanin in association with an adjuvant may induce a humoral immune response against these tumour associated antigens. ${ }^{159} 160$ However, sialyl-Tn positivity is related, either directly or indirectly, to resistance to adjuvant chemotherapy in patients with breast cancer. ${ }^{161}$

\section{Concluding remarks}

Since early observations in the late 1970 s, suggesting a role for complex carbohydrates in cancer biology, the contribution of some cancer related oligosaccharide sequences to the expression of an invasive phenotype has been established. The expression of some of these structures shows a strict correlation with tumour aggression and their detection by lectins or monoclonal antibodies is useful for the clinical management of patients with cancer. The use of glycosylation inhibitors, such as swainsonine, as antineoplastic agents or attempts to use the sialyl-Tn epitope for active anticancer immunotherapy are promis- ing new approaches for the treatment of cancer. The goal for the next few years will be the elucidation of the precise molecular interactions involving carbohydrate chains in the hope that this will facilitate the design of drugs directed against specific steps of cancer progression.

I am grateful to Drs Inka Brockhausen, The Hospital for Sick Children, Toronto, Canada, and Joseph T.Y. Lau, Roswell Park Cancer Institute, Buffalo, NY, USA, for their comments on the manuscript. Research was supported by grants (quote $60 \%$ and $40 \%$ ) from M.U.R.S.T., Rome.

1 Kornfeld R, Kornfeld S. Assembly of asparagine-linked oligosaccharides. Ann Rev Biochem 1985;54:631-64.

2 Brockhausen I. Biosynthesis of O-glycans of the $\mathrm{N}$-acetylgalactosamine $\alpha$-Ser/Thr linkage type. In: Montreuil J, Schachter H, Vliegenthart JFG, eds. Glycoproteins. Amsterdam: Elsevier, 1995:201-59.

3 Warren L, Buck CA, Tuszynski GP. Glycopeptide changes and malignant transformation. A possible role for carbohydrate in malignant behavior. Biochim Biophys Acta 1978;516:97-127.

4 Feizi $T$. Demonstration by monoclonal antibodies that carbohydrate structures of glycoproteins and glycolipids
are onco-developmental antigens. Nature $1985 ; 314: 53-7$.

5 Brockhausen I. Clinical aspects of glycoprotein biosynthesis. Crit Rev Clin Lab Sci 1993;30:65-151.

6 Irimura T, Gonzalez R, Nicolson GL. Effect of tunicamycin on B16 metastatic melanoma cell surface glycoproteins and blood-borne arrest and survival properties. Cancer Re 1981;41:3411-18

7 Humphries MJ, Matsumoto K, White SL, Olden K Oligosaccharide modification by swainsonine treatment inhibits pulmonary colonization by B16-F10 murine melanoma cells. Proc Natl Acad Sci USA 1986;83:1752-6.

8 Humphries MJ, Matsumoto K, White SL, Olden K. Inhibition of experimental metastasis by castanospermine in mice: blockage of two distinct stages of tumor colonization by oligosaccharide processing inhibitors. Cancer Res 1986 46:5215-22.

9 Pulverer G, Beuth J, Ko HL, Yassin A, Ohshima Y, Roszkowski K, et al. Glycoprotein modification of sarcoma L-1 tumor cells by tunicamycin, swainsonine, bromoconduritol, or 1-desoxynojirimycin treatment inhibits their metastatic lung colonization in Balb/c-mice. $f$ Cancer Res Clin Oncol 1988;114:217-20.

10 Sargent NSE, Price JE, Darling DL, Flynn MP, Tarin D. Effects of altering surface glycoprotein composition on metastatic colonization potential of murine mammary tumor cells. Br f Cancer 1987;55:21-8.

11 Dennis JW, Koch K, Beckner D. Inhibition of human HT-29 colon carcinoma growth in vitro and in vivo by swainsonine and human interferon- $\alpha 2.7$ Natl Cancer Inst 1989;81:1028-33.

12 Dennis JW, Koch K, Yousefi S, Van der Elst I. Growth inhibition of human melanoma tumor xenografts in athymic bition of human melanoma tumor xenografts in athymic
nude mice by swainsonine. Cancer Res 1990;50:1867-72.

13 Humphries MJ, Matsumoto K, White SL, Molyneux RJ Olden K. Augmentation of murine natural killer cell activity by swainsonine, a new antimetastatic immunomodulator. Cancer Res 1988;48:1410-15.

14 Newton SA, White SL, Humphries MJ, Olden K. Swainsonine inhibition of spontaneous metastasis. $\mathcal{F}$ Natl Cancer Inst 1989;81:1024-8.

15 Dennis JW. Effects of swainsonine and polyinosinic:polycytidylic acid on murine tumor cell growth and metastasis. Cytidylic acid on murine tum

16 Goss PE, Baptiste J, Fernandes B, Baker M Dennis JW. A phase I study of swainsonine in patients with advanced malignancies. Cancer Res 1994;54:1450-7.

17 Kijima-Suda I, MiyamotoY, Toyoshima S, Itoh M, Osawa T Inhibition of experimental metastasis of mouse colon adenocarcinoma 26 sublines by a sialic acid:nucleoside conjugate having sialyltransferase inhibiting activity. Cancer Res 1986;46:858-62.

18 Wagner HE, Thomas P, Wolf BC, Rapoza A, Steele G. Inhibition of sialic acid incorporation prevents hepatic bition of sialic acid incorporation
metastases. Arch Surg 1990;125:351-4.

19 Dennis JW, Waller C, Timpl R, Schirrmacher V. Surface sialic acid reduces attachment of metastatic tumor cells to sialic acid reduces attachment of metastatic tumor cells to
collagen type IV and fibronectin. Nature 1982;300:274-6.

20 Kijima-Suda I, Miyazawa T, Itoh M, Toyoshima S, Osawa T. Possible mechanism of inhibition of experimental pulmonary metastasis of mouse colon adenocarcinoma 26 sublines by a sialic acid:nucleoside conjugate. Cancer Res 1988;48:3728-32.

21 Gallagher JT, Morris A, Dexter TM. Identification of two binding sites for wheat-germ agglutinin on polylactosamine-type oligosaccharides. Biochem $\mathcal{F} 1985$ 231:115-22.

22 Tao TW, Burger MM. Non-metastasizing variants selected from metastasizing melanoma cells. Nature 1977; 270:437-8.

23 Yogeeswaran G, Salk PL. Metastatic potential is positively correlated with cell surface sialylation of cultured murine tumor cell lines. Science 1981;212:1514-16. 
24 Dennis JW. Partial reversion of the metastatic phenotype in a wheat germ agglutinin-resistant mutant of the murine tumor cell line MDAY-D2 selected with Bandeirae simplicifolia seed lectin. $\mathcal{F}$ Natl Cancer Inst 1985;74:111119.

25 Dennis JW. Different metastatic phenotypes in two genetic classes of wheat germ agglutinin-resistant tumor cell classes of wheat germ agglutinin-resi
mutants. Cancer Res 1986;46:4594-600.

26 Dennis JW, Carver JP, Schachter H. Asparagine-linked oligosaccharides in murine tumor cells: comparison of WGA-resistant (WGA) nonmetastatic mutant and a related WGA-sensitive (WGA ${ }^{s}$ ) metastatic line. $\mathcal{f}$ Cell Biol 1984;99:1034-44.

27 Dennis JW, Lafertè S, Fukuda M, Dell A, Carver J. Asn-linked oligosaccharides in lectin-resistant tumor cell mutants with varying metastatic potential. Eur $\mathcal{F}$ Biochem mutants with varying

28 Ishikawa M, Dennis JW, Man S, Kerbel RS. Isolation and characterization of spontaneous wheat germ agglutininresistant human melanoma mutants displaying remarkably different metastatic profiles in nude mice. Cancer Res 1988;48: $665-70$.

29 Ishikawa M, Kerbel RS Characterization of a metastasisdeficient lectin-resistant human melanoma mutant. Int $\mathcal{F}$ Cancer 1989;43:134-9.

30 Irimura T, Tressler RJ, Nicolson GL. Sialoglycoproteins of murine RAW 117 large cell lymphoma/lymphosarcoma sublines of various metastatic colonization properties. Exp Cell Res 1986;165:403-16.

31 Benedetto A, Elia G, Sala A, Belardelli F. Hyposialylation of high-molecular-weight membrane glycoproteins parallels the loss of metastatic potential in wheat-germ agglutininresistant Friend leukemia cells. Int $\mathcal{f}$ Cancer 1989;43:12633.

32 Collard JC, Schijven JF, Bikker A, La Riviere G, Bolscher JGM, Roos E. Cell surface sialic acid and the invasive and metastatic poten

33 Morgenthaler J, Kemmner W, Brossmer R. Sialic aciddependent cell adhesion to collagen IV correlates with in vivo tumorigenicity of the human colon carcinoma vivo tumorigenicity of the human colon carcinoma
sublines HCT116, HCT116a and HCT116b. Biochem Bublines HCT116, HCT116a and Hes Commun 1990;171:860-6.

34 Passaniti A, Hart GW. Cell surface sialylation and tumor metastasis. Metastatic potential of B16 melanoma variants correlates with their relative numbers of specific penultimate oligosaccharide structures. F Biol Chem 1988 263:7591-603.

35 Jiang M, Passaniti A, Penno MB, Hart GW. Adrenal carcinoma tumor progression and penultimate cell surface carcinoma tumor progression and penultimate

36 Cornil I, Kerbel RS, Dennis JW. Tumor cell surface $\beta 1,4$-linked galactose binds to lectin(s) on microvascular endothelial cell and contributes to organ colonization f Cell Biol 1990;111:773-81.

37 Penno MB, Passaniti A, Fridman R, Hart GW, Jordan C, Kumar S, et al. In vitro galactosylation of a $110-\mathrm{kDa}$ glycoprotein by an endogenous cell surface galactosyltransferase correlates with the invasiveness of adrenal carcinoma cells. Proc Natl Acad Sci USA 1989;86:6057-61.

38 Finne J, Makela PH. Cleavage of the polysialosyl units of brain glycoproteins by a bacteriophage endosialidase. f Biol Chem 1985;260:1265-70.

39 Rutishauser U, Acheson A, Hall AK, Mann DM, Sunshine J. The neural cell adhesion molecule (NCAM) as a regulator of cell-cell interactions. Science 1988;240:53-7.

40 Acheson A, Sunshine JL, Rutishauser U. NCAM polysialic acid can regulate both cell-cell and cell-substratum interactions. $\mathcal{F}$ Cell Biol 1991;114:143-53.

41 Figarella-Branger DF, Durbec PL, Rougon GN. Differentia spectrum of expression of neural cell adhesion molecule isoforms and $\mathrm{L} 1$ adhesion molecules on human neuroectodermal tumors. Cancer Res 1990;50:6364-70.

42 Ceck M, Muller EJ, Schol DJ, Figdor CG, Bock E Bitter-Suermann $\mathrm{D}$, et al. Expression of neural cell
adhesion molecule-related sialoglycoprotein in small cell adhesion molecule-related sialoglycoprotein in small cell lung cancer and neuroblastoma cell
CHP-212. Cancer Res 1990;50:1102-6.

43 Livingston BD, Jacobs JL, Glick MC, Troy F. Extended polysialic acid chains $(n>55)$ in glycoproteins from human neuroblastoma cells. f Biol Chem 1988 263:9443-8

44 Komminoth P, Roth J, Lackie PM, Bitter-Suermann D, Heitz PU. Polysialic acid of the neural cell adhesion molecule distinguishes small cell lung carcinoma from carcinoids. Am ₹ Pathol 1991;139:297-304.

45 Scheidegger EP, Lackie PM, Papay J, Roth J. In vitro and in vivo growth of clonal sublines of human small cell lung
carcinoma is modulated by polysialic acid of the neural cell carcinoma is modulated by polysialic acid of the

46 Komminoth P, Roth J, Saremaslani P, Matias-Guiu X, Wolfe HJ, Heitz PU. Polysialic acid of the neural cell adhesion molecule in the human thyroid: a marker for medullary thyroid carcinoma and primary C-cell hyperplasia. An immunohistochemical study on 79 thyroid lesions. Am Surg Pathol 1994;18:399-411.

47 Roth J, Zuber C, Wagner P, Taatjes D, Weisgerber C, Heitz PU, et al. Reexpression of poly(sialic acid) units of the neural cell adhesion molecule in Wilms tumors. Proc Nat Acad Sci USA 1988;85:2999-3003.

48 Dall'Olio F, Malagolini N, Di Stefano G, Minni F, Marrano D Serafini-Cessi F. Increased CMP-NeuAc:Gal 1 1,4GIcNAc-R $\alpha 2,6$ sialyltransferase activity in human colorectal cancer $\alpha 2,6$ sialyltransferase activity in hum
tissues. Int $\mathcal{F}$ Cancer 1989;44:434-9.
49 Sata T, Roth J, Zuber C, Stamm B, Heitz PU. Expression of $\alpha 2,6$-linked sialic acid residues in neoplastic but not in normal human colonic mucosa. Am f Pathol 1991; 139: $1435-48$

50 Dall'Olio F, Trerè D. Expression of $\alpha 2,6$-sialylated sugar chains in normal and neoplastic colon tissues. Detection by digoxigenin-conjugated Sambucus nigra agglutinin. Eur f Histochem 1993;37:257-65.

51 Yamashita K, Fukushima K, Sakiyama T, Murata F, Kuroki $M$, Matsuoka Y. Expression of Sia $\alpha 2,6 \mathrm{Gal} 1$, 4GlcNAc residues on sugar chains of glycoproteins including carcinoembryonic antigens in human colon adenocarcinoma: applications of Trichosanthes japonica agglutinin I for early diagnosis. Cancer Res 1995;55:1675-9.

52 Dall'Olio F, Malagolini N, Di Stefano G, Ciambella M, Serafini-Cessi F. Postnatal development of rat colon epithelial cells is associated with changes in the expression of $\beta 1,4-N$-acetylgalactosaminyltransferase involved in the synthesis of $\mathrm{Sd}^{\mathrm{a}}$ antigen and of $\alpha 2,6$ sialyltransferase towards $N$-acetyllactosamine. Biochem $\mathcal{f}$ 1990;270:51924.

53 Vertino-Bell A, Ren J, Black JD, Lau JTY. Developmental regulation of $\beta$-galactoside $\alpha 2,6$-sialyltransferase in small intestine epithelium. Dev Biol 1994;165:126-36.

54 Dall'Olio F, Malagolini N, Serafini-Cessi F. The expression of soluble and cell-bound $\alpha 2,6$ sialyltransferase in human colonic carcinoma $\mathrm{CaCo}-2$ cells correlates with the degree of enterocytic differentiation. Biochem Biophys Res Com mun 1992;184:1405-10.

55 Hakomori S, Patterson CM, Nudelman E, Sekiguchi KA. A monoclonal antibody directed to $\mathrm{N}$-acetylneuraminosyl$\alpha 2-6$-galactosyl residue in gangliosides and glycoproteins. f Biol Chem 1983;258:11819-22.

56 Nilsson O, Lindholm L, Holmgren J, Svennerholm L. Monoclonal antibodies raised against NeuAc $\alpha 2$ 6neolactotetraosylceramide detect carcinoma-associated gangliosides. Biochim Biophys Acta 1985;835:577-83.

57 Easton EW, Bolscher JGM, van den Eijnden DH. Enzymatic amplification involving glycosyltransferases forms the basis for the increased size of asparagine-linked glycans at the surface of NIH 3T3 cells expressing the N-ras proto-oncogene. 7 Biol Chem 1991;266:21674-80.

58 Le Marer N, Laudet V, Svensson EC, Cazlaris H, Van Hille B, Lafrou C, et al. The c.Ha-ras oncogene induces increased expression of $\beta$-galactoside $\alpha 2,6$-sialyltransferase in rat fibroblast (FR3T3) cells. Glycobiology 1992;2:49-56

59 Le Marer N, Stehelin D. High alpha-2,6-sialylation of $\mathrm{N}$-acetyllactosamine sequences in ras-transformed rat fibroblasts correlates with high invasive potential. Glycobiology 1995;5:219-26.

60 Gessner P, Riedl S, Quentmaier A, Kemmner W. Enhanced activity of CMP-NeuAc:Gal $\beta 1-4$ GlcNAc: $\alpha 2,6$-sialylactivity of CMP-NeuAc:Gal $\beta 1-4 \mathrm{GlCNAc:} \alpha 2,6$-sialyltransferase in metastasizing human colorectal tumor tissue
and serum of tumor patients. Cancer Lett 1993;75:143-9.

61 Dall'Olio F, Malagolini N, Di Stefano G, Ciambella M Serafini-Cessi F. $\alpha 2,6$-sialylation of $N$-acetyllactosaminic sequences in human colorectal cancer cell lines. Relationship with non-adherent growth. Int $\mathcal{f}$ Cancer 1991; 47:291-7.

62 Bresalier RS, Rockwell RW, Dahiya R, Duh OY, Kim YS. Cell surface sialoprotein alterations in metastatic murine colon cancer cell line selected in an animal model for colon colon cancer cell line selected in an animal model for
cancer metastasis. Cancer Res 1990;50:1299-307.

63 Piscatelli JJ, Cohen SA, Berenson CS, Lance P. Determinants of differential liver-colonizing potential of variants of the MCA-38 murine colon cancer cell line. Clin Exp Metastasis 1995;13:141-50.

64 Dall'Olio F, Malagolini N, Serafini-Cessi F. Enhanced CMP-NeuAc:Gal $\beta 1,4$ GlcNAc-R $\quad \alpha 2,6$ sialyltransferase activity of human colon cancer xenografts in athymic nude mice and of xenograft-derived cell lines. Int $f$ Cancer 1992 ; mice and of

65 Takano R, Muchmore E, Dennis JW. Sialylation and malignant potential in tumor cell glycosylation mutants. Glycobiology 1994;4:665-74

66 Dall'Olio F, Chiricolo M, Lollini P, Lau JTY. Human colon cancer cell lines permanently expressing $\alpha 2,6$-sialylated sugar chains by transfection with rat $\beta$-galactoside $\alpha 2,6$ sugar chains by transfection with rat $\beta$-galactoside $\alpha 2,6$
sialyltransferase cDNA. Biochem Biophys Res Commun 1995;211;554-61.

67 Santer UV, Gilbert F, Glick MC. Change in glycosylation of membrane glycoproteins after transfection of NIH $3 \mathrm{~T}$ with human tumor DNA. Cancer Res 1984;44:3730-5.

68 Collard JG, Van Beek WP, Janssen JWG, Schijven JF. Transfection by human oncogenes: Concomitant induction of tumorigenicity and tumor-associated membrane altertumorigenicity and tumor-associated

69 Yamashita K, Ohkura T, TachibanaY, Takasaki S, Kobata A. Comparative study of the oligosaccharides released from baby hamster kidney cells and their polyoma transformants by hydrazinolysis. $₹$ Biol Chem 1984;259:10834-40.

70 Pierce M, Arango J. Rous Sarcoma Virus-transformed bab hamster kidney cells express higher levels of asparaginelinked tri- and tetraantennary glycopeptides containing [GlcNAc- $\beta(1,6)$ Man- $\alpha(1,6) M$ an] and poly- $N$-acetyllactosamine sequences than baby

71 Dennis JW, Kosh K, Bryce DM, Breitman M. Oncogenes conferring metastatic potential induce increased branching of Asn-linked oligosaccharides in rat 2 fibroblasts. Oncogene 1989;4:835-60. 
72 Dennis JW, Lafertè S, Waghorne C, Breitman ML, Kerbe RS. $\beta 1-6$ branching of Asn-linked oligosaccharides is directly associated with metastasis. Science 1987; 236:582-5.

73 Lafertè S, Dennis JW. Purification of two glycoproteins expressing $\beta 1-6 b r a n c h e d ~ A s n-l i n k e d ~ o l i g o s a c c h a r i d e s$ from metastatic tumor cells. Biochem f 1989;259:569-76.

74 Heffernan M, Yousefi S, Dennis JW. Molecular characterization of P2B/LAMP-1, a major protein target of a metastasis-associated oligosaccharide structure. Cancer Res 1989;49:6077-84.

75 Yagel S, Feinmesser R, Wafhorne C, Lala PK, Breitman ML Dennis JW. Evidence that $\beta 1,6$ branched Asn-linked oligosaccharides on metastatic tumor cells facilitate invasion of basement membranes. Int f Cancer 1989; invasion of

76 Takano $R$, Nose $M$, Tetsuro N, Kyogoku M. Increase of B1-6-branched oligosaccharides in human esophageal carcinomas invasive against surrounding tissue in vivo and in vitro. Am F Pathol 1990;137:1007-11

77 Fernandes B, Sagman U, Auger M, Demetrio M, Dennis JW. $\beta 1-6$ branched oligosaccharides as markers of tumor progression in human breast and colon neoplasia. Cancer Res 1991;51:718-23.

78 Yousefi S, Higgins E, Daoling $Z$, Pollex-Kruger A, Hindsgaul O, Dennis JW. Increased UDP-GlcNAc:Gal $\beta 1$ 3 GalNAc-R (GlcNAc to GalNAc) $\beta-1,6-N$-acetylglucosaminyltransferase activity in metastatic murine tumor cell lines. Control of polylactosamine synthesis. $\mathcal{F}$ Biol Chem 1991;266: 1772-82.

79 Brockhausen I, Kuhns W, Schachter H, Matta KL, Sutherland DR, Baker MA. Biosynthesis of $O$-glycans in leukocytes from normal donors and from patients with leukemia: increase in $O$-glycan core 2 UDPGlcNAc:Gal $\beta 3$ GalNAc $\alpha-R$ (GlcNAc to GalNAc) $\beta(1-6)-$ $\mathrm{N}$-acetylglucosaminyltransferase in leukemic cells. Cancer Res 1991;51:1257-63.

80 Saitoh O, Piller F, Fox RI, Fukuda M. T-lymphocytic leukemias express complex, branched $O$-linked oligosaccharides on a major sialoglycoprotein, leukosialin. Blood 1991;77:1491-9.

81 Fukuda $M$. Leukosialin, a major $O$-glycan-containing sialoglycoprotein defining leukocyte differentiation and malignancy. Glycobiology 1991;1:347-56.

82 Vavasseur F, Dole K, Yang J, Matta KL, Myerscough N, Corfield A, et al. O-glycan biosynthesis in human colorectal adenoma cells during progression to cancer. Eur 7 Biochem 1994;222:415-24.

83 Yang JM, Byrd JC, Siddiki BB, Chung YS, Okuno M, Sowa $\mathrm{M}$, et al. Alterations of $O$-glycan biosynthesis in human colon cancer tissues. Glycobiology 1994;4:873-84.

84 Van den Eijnden DH, Koenderman AHL, Schiphorst WECM. Biosynthesis of blood group i-active polylactosaminoglycans. F Biol Chem 1988;263:12461-71.

85 Piller F, Cartron JP, Maranduba A, Veyrieres A, Leroy Y, Fournet B. Biosynthesis of blood group I antigens. $\mathcal{F}$ Biol Chem 1984;259: 13385-90.

$86 \mathrm{Gu}$ J, Nishikawa A, Fujii S, Gasa S, Taniguchi N. Biosynthesis of blood group I and $\mathrm{i}$ antigens in rat tissues. $\mathcal{f} \mathrm{Biol}$ Chem 1992;267:2994-9.

87 Fukuda $M$. Cell surface glycoconjugates as oncodifferentiation markers in hematopoietic cells. Biochim Biophys Acta 1985;780: 119-50.

88 Schuessler $M H$, Pintado $S$, Welt $S$, Real FX, Xu $M$, Melamed MR, et al. Blood group and blood-group-related antigens in normal pancreas and pancreas cancer: antigens in normal pancreas and pancreas cancer: in pancreatic cancer. Int $\mathcal{f}$ Cancer 1991;47:180-7.

89 Itai S, Nishikata J, Takahashi N, Tanaka O, MatsubaraY, Hasegawa $\mathrm{S}$, et al. Differentiation-dependent expression of I and sialyl I antigens in the developing lung of human embryos and in lung cancers. Cancer Res 1990;50:7603-11.

90 Mizoguchi A, Takasaky S, Maeda S, Kobata A. Changes in asparagine-linked sugar chains of human promyelocytic leukemic cells (HL-60) during monocytoid differentiation and myeloid differentiation. 7 Biol Chem 1984;259:11949-57.

91 Youakim A, Romero PA, Yee K, Carlsson SR, Fukuda M Herscovics A. Decrease in polylactosamine glycans associated with lysosomal membrane glycoproteins during differentiation of $\mathrm{CaCo}-2$ human colonic adenocarcinom cells. Cancer Res 1989;49:6889-95.

92 Watkins WM. Biochemistry and genetics of the ABO, Lewis and $\mathrm{P}$ blood group systems. In: Harris $\mathrm{H}$, Hirschlorm $\mathrm{K}$, eds. Advances in human genetics. New York: Plenum Press, 1980:1-136.

93 Hakomori S. Aberrant glycosylation in tumors and tumorassociated carbohydrate antigens. Adv Cancer Res 1989; 52:257-331.

94 Stenersen TC, Debelsteen E. Changes in the glycosylation pattern of histo-blood group antigens in benign, premalignant and malignant laryngeal epithelial lesions. APMIS 1992;100(Suppl 27): 139-48.

95 Itzkowitz S. Carbohydrate changes in colon carcinoma. APMIS 1992;100(Suppl 27): 173-80.

96 Ørntoft TF. Carbohydrate changes in bladder carcinomas. APMIS 1992;100(Suppl 27): 181-7.

97 Yamamoto F, Clausen H, White T, Marken J, Hakomori S. Molecular genetic basis of the histo-blood group ABO system. Nature 1990;345:229-33.

98 Greenwell P, Yates AD, Watkins WM. UDP-N acetylgalactosamine as a donor substrate for the glycosyltransferase encoded by the $B$ gene at the human blood group ABO locus. Carbohydr Res 1986;149: 149-70
99 David L, Leitao D, Sobrinho-Simoes M, Bennet EP, White $\mathrm{T}$, Mandel U, et al. Biosynthetic basis of incompatible histo-blood group antigen expression: anti-A transferase antibodies reactive with gastric cancer tissue of type $\mathrm{O}$ individuals. Cancer Res 1993;53:5494-500.

100 Yuan M, Itzkowitz SH, Palekar A, Shamsuddin AM, Phelps PC, Trump BF, et al. Distribution of blood group antigens $\mathrm{A}, \mathrm{B}, \mathrm{H}$, Lewis ${ }^{\mathrm{a}}$, and Lewis ${ }^{\mathrm{b}}$, in human norma etal, and malignant colonic tissue. Cancer Res 1985 45:4499-511.

101 Itzkowitz SH, Yuan M, Ferrel LD, Ratcliffe RM, Chung YS, Satake K, et al. Cancer-associated alterations of blood group antigen expression in the human pancreas. $\mathcal{F}$ Nat Group antigen expression in $1987 ; 79: 425-34$.

102 Okada Y, Arima T, Togawa K, Nagashima H, Jinno K, Moriwaki $\mathrm{S}$, et al. Neoexpression of $\mathrm{ABH}$ and Lewis blood group antigens in human hepatocellular carcinomas. $\mathscr{f}$ Natl Cancer Inst 1987;78:19-28.

103 Ørntoft TF, Wolf H, Clausen H, Dabelsteen E, Hakomor $\mathrm{S}$. Blood group $\mathrm{ABH}$-related antigens in normal and malignant bladder urothelium: possible structural basis for the deletion of type- 2 chain $\mathrm{ABH}$ antigens in invasive carcinomas. Int $f$ Cancer 1989;43:774-80.

104 Mandel U, Langkilde NC, Ørntoft TF, HamiltonTherkildsen M, Karkov J, Reibel J, et al Expression of histo-blood-group-gene-defined glycosyltransferases in normal and malignant epithelia: correlation with A/B-carbohydrate expression. Int $\mathcal{f}$ Cancer 1992;52:7-12.

105 Metoki R, Kakudo K, Tsuji Y, Teng N, Clausen H, Hakomori S. Deletion of histo-blood group $\mathrm{A}$ and $\mathrm{B}$ antigens and expression of incompatible $\mathrm{A}$ antigen in ovarian cancer. $\mathcal{F}$ Natl Cancer Inst 1989;81:1 151-7.

106 Matsumoto $\mathrm{H}$, Muramatsu H, Shimotakahara T, Yanagi M, Nishijima H, Mitani N, et al. Correlation of expression of $\mathrm{ABH}$ blood group carbohydrate antigens with metatatic potential in human lung carcinomas. Cancer 1993;72:75-81.

107 Gwin JL, Klein-Szanto AJ, Zhang SY, Agarwal P, Rogatko A, Keller SM. Loss of blood group antigen A in non-smal cell lung cancer. Ann Surg Oncol 1994;1:423-7.

108 Jordon DA, Jagirdar J, Kaneko M. Blood group antigens, Lewis $^{x}$ and Lewis ${ }^{y}$ in the diagnostic discrimination of malignant mesothelioma versus adenocarcinoma. $A m \mathcal{F}$ Pathol 1989;135:931-7.

109 Hanish FG, Hanski C, Hasegawa A. Sialyl Lewis ${ }^{x}$ antigen as defined by monoclonal antibody $\mathrm{AM}-3$ is a marker of dysplasia in the colonic adenoma-carcinoma sequence. Cancer Res 1992;52:3138-44.

110 Cooper HS, Malecha MJ, Bass C, Fagel PL, Steplewski Z Expression of blood group antigens $\mathrm{H}-2, \mathrm{Le}^{\mathrm{y}}$, and sialylated-Le in human colorectal carcinoma. Am f Pathol 1991;138:103-10.

111 Sakamoto J, Watanabe $\mathrm{T}$, Tokumaru $\mathrm{T}$, Takagi $\mathrm{H}$, Nakazato H, Lloyd KO. Expression of Lewis ${ }^{\mathrm{a}}$, Lewis ${ }^{\mathrm{b}}$, Lewis $^{\mathrm{x}}$, Lewis ${ }^{\mathrm{y}}$, sialyl-Lewis ${ }^{\mathrm{a}}$, and sialyl-Lewis ${ }^{\mathrm{x}}$ blood group antigen in human gastric carcinoma and in normal group antric tissue. Cancer Res 1989;49:745-52.

112 Cordon-Cardo C, Reuter VE, Finstad CL, Sheinfels J, Lloyd KO, Fair WR, et al. Blood group-related antigens in human kidney: modulation of Lewis determinants in renal cell carcinoma. Cancer Res 1989;49:212-8.

113 Singhal AK, Ørntoft TF, Nudelman E, Nance S, Schibing $\mathrm{L}$, Stroud MR, et al. Profiles of Lewis ${ }^{\mathrm{x}}$-containing glycoproteins and glycolipids in sera of patients with glycoproteins and glycolipids in sera of pa

114 Magnani JL, Nilsson B, Brockhaus M, Zopf D, Steplewsk $\mathrm{Z}$, Koprowski H, et al. A monoclonal antibody-defined antigen associated with gastrointestinal cancer is ganglioside containing sialylated lacto- $\mathrm{N}$-fucopentaose II f Biol Chem 1982;257:14365-9.

115 Phillips ML, Nudelman E, Gaeta FCA, Perez M, Singha AK, Hakomori S, et al. ELAM-1 mediates cell adhesion by recognition of a carbohydrate ligand, sialyl-Le ${ }^{x}$ Science 1990;250:1130-2.

116 Walz G, Aruffo A, Kolanus W, Bevilacqua M, Seed B. Recgnition by ELAM-1 of the sialyl-Le ${ }^{x}$ determinant on myeloid and tumor cells. Science 1990;250:1132-5.

117 Bergh EL, Robinson MK, Mansson O, Butcher EC, Magnani JL. A carbohydrate domain common to both sialyl Le and sialyl $\mathrm{Le}^{\mathrm{x}}$ is recognized by the endothelial cell adhesion molecule ELAM-1. F Biol Chem 1991;266:14869-72.

118 Foxall C, Watson SR, Dowbenko D, Fennie C, Lasky LA, Kiso $M$, et al. The three members of the selectin receptor family recognize a common carbohydrate epitope, the sia-
lyl Lewis ${ }^{x}$ oligosaccharide. $\mathcal{F}$ Cell Biol 1992;117:895-902.

119 Dejana E, Martin-Padura I, Lauri D, Bernasconi S, Ban MR, Garofalo A, et al. Endothelial leukocyte adhesion to vascular endothelium is inhibited by an antibody to Lewis fucosylated type 1 carbohydrate chain. Lab Invest 1992;66:324-30.

120 Kojima N, Handa K, Newman W, Hakomori S. Inhibition of selectin-dependent tumor cell adhesion to endothelia cells and platelets by blocking $O$-glycosylation of these cells. Biochem Biophys Res Commun 1992;182:1288-95.

121 Takada A, Ohmori K, Yoneda T, Tsuyuoka K, Hasegawa A, Kiso $M$. Contribution of carbohydrate antigens sialyl Lewis ${ }^{\mathrm{a}}$ and sialyl Lewis ${ }^{\mathrm{x}}$ to adhesion of human cancer cel to vascular endothelium. Cancer Res 1993;53:354-61.

122 Tozeren A, Kleinman HK, Grant DS, Morales D, Mercurio AM, Byers SW. E-selectin-mediated dynamic interactions of breast- and colon-cancer cells with endothelial-cell monolayers. Int f Cancer 1995;60:426-31. 
123 Hasegawa $\mathrm{H}$, Watanabe $\mathrm{M}$, Arisawa $\mathrm{Y}$, Teramoto T, Kodaira S, Kitajima M. Carbohydrate antigens and liver metastasis in colorectal cancer. fpn f Clin Oncol 1993; 23:336-41.

124 Ogawa J, Tsurumi T, Yamada S, Koide S, Shohtsu A. Blood vessel invasion and expression of sialyl Lewis ${ }^{x}$ and proliferating cell nuclear antigen in stage I non-small cell lung cancer. Relation to postoperative recurrence. Cancer 1994 73:1177-83

125 Ogawa J, Sano A, Inoue H, Koide S. Expression of Lewisrelated antigens and prognosis in stage I non-small cel lung carcinoma. Ann Thorac Surg 1995;59:412-5

126 Kageshita T, Hirai S, Kimura T, Hanai N, Ohta S, Ono T. Association between sialyl Lewis ${ }^{a}$ expression and tumor progression in melanoma. Cancer Res 1995;55:1748-51.

127 Nakasaki $H$, Mitomi T, Noto T, Ogoshi $K$, Hanaue $H$, Tanaka Y, et al. Mosaicism in the expression of tumorassociated carbohydrate antigens in human colonic and associated carbohydrate antigens in human

128 Hoff SD, Matsushita Y, Ota DM, Cleary KR, Yamori T, Hakomori S, et al. Increased expression of sialyl-dimeric $\mathrm{Le}^{\mathrm{x}}$ antigen in liver metastases of human colorectal carcinoma. Cancer Res 1989;49:6883-8.

129 Matsushita Y, Nakamori S, Seftro EA, Hendrix MJC Irimura T. Human colon carcinoma cells with increased invasive capacity obtained by selection for sialyl-dimeric Le ${ }^{\mathrm{x}}$ antigen. Exp Cell Res 1991;196:20-5.

130 Matsusako T, Muramatsu H, Shirahama T, Muramatsu T, Ohi Y. Expression of a carbohydrate signal sialyl-dimeric $\mathrm{Le}^{\mathrm{x}}$ antigen, is associated with metastatic potential of tranLe antigen, is associated with metastatic potential of tranchem Biophys Res Commun 1991;181:1218-22.

131 Blasco E, Torrado J, Belloso L, Arocena F, Cuadrado E. T-antigen: a prognostic indicator of high recurrence index in transitional carcinoma of the bladder. Cancer 1988; 61:1091-5.

132 Coon J, Weinstein RS, Summers J. Blood group precursor T-antigen expression in human urinary bladder carcinoma. Am $\mathcal{F}$ Clin Pathol 1982;77:692-9.

133 Limas C, Lange P. T-antigen in normal and neoplastic urothelium. Cancer 1986;58:1236-45.

134 Summers JL, Coon JS, Ward RM, Falor WH, Mille AW III, Weinstein RS. Prognosis of the urinary bladder based upon tissue blood group ABH and Thomsen-Friedenreich upon tissue blood group ABH and Thomsen-Friedenreich antigen status and

135 Nishiyama T, Matsumoto Y, Watanabe H, Fujiwara M, Sato S. Detection of Tn antigen with Vicia villosa agglutinin in urinary bladder cancer: its relevance to the patient's clinical course. $\mathcal{F}$ Natl Cancer Inst 1987;78:1113-17.

136 Fenlon S, Ellis IO, Bell J, Todd JH, Elston CW, Blamey RW. Helix pomatia and Ulex europaeus lectin binding in human breast carcinoma. F Pathol 1987;152:169-76.

137 Leathem AJ, Brooks SA. Predictive value of lectin binding on breast-cancer recurrence and survival. Lancet 1987; i: $1054-6$.

138 Springer GF. Tn epitope ( $N$-acetyl-D-galactosamine $\alpha-O$ serine/threonine) density in primary breast carcinoma: a functional predictor of aggressiveness. Mol Immunol 1989, 26: $1-5$.

139 Boland CR, Montgomery CK, Kim YS. Alteration in human colonic mucin occurring with cellular differentiation and malignant transformation. Proc Natl Acad Sci USA 1982;79:2051-5.

140 Itzkowitz SH, Yuan M, Montgomery CK, Kjeldsen $T$, Takahashi HK, Bigbee WL, et al. Expression of Tn, sialosyl Tn and T antigens in human colon cancer. Cancer Res syl $\mathrm{Tn}$ and $\mathrm{T}$ antigen

141 Yuan M, Itzkowitz SH, Boland CR, Kim YD, Tomita JT, Palekar A, et al. Comparison of T-antigen expression in normal, premalignant and malignant human colonic tissues using lectin and antibody immunohistochemistry. Cancer Res 1986;46:4841-7.

142 Ørntoft TF, Harving N, Langkilde NC. O-linked mucintype glycoproteins in normal and malignant colon mucosa: lack of $\mathrm{T}$ antigen expression and accumulation of $\mathrm{Tn}$ and sialosyl-Tn antigens in carcinomas. Int $f$ Cancer 1990; 45:666-72.

143 Vavasseur F, Yang JM, Dole K, Paulsen H, Brockhausen I. Synthesis of $O$-glycan core 3: Characterization of UDP-
GlcNAc: GalNAc-R $\beta 3-N$-acetylglucosaminyltransferase activity from colonic mucosal tissues and lack of the activity in human cancer cell lines. Glycobiology 1995;5:351-7.

144 Itzkowitz SH, Bloom EJ, Kokal WA, Modin G, Hakomori $\mathrm{S}$, Kim YS. Sialosyl-Tn. A novel mucin antigen associated with prognosis in colorectal cancer patients. Cancer 1990; with prognosis

145 Kjeldsen T, Clausen H, Hirohashi S, Ogawa T, Iijima $H$, Hakomori S. Preparation and characterization of monoclonal antibodies directed to the tumor-associated $O$-linked sialosyl-2-6 $\alpha-N$-acetylgalactosaminyl (sialosylTn) epitope. Cancer Res 1988;48:2214-20.

146 Itzkowitz S, Kjeldsen T, Friera A, Hakomori S, Yang US, Kim YS. Expression of Tn, sialosyl Tn, and T antigens in human pancreas. Gastroenterology 1991;100:1691-700.

147 Osako M, Yonezawa S, Siddiki B, Huang J, Ho JJ, Kim YS Immunohistochemical study of mucin carbohydrates and core proteins in human pancreatic tumors. Cancer core proteins in

148 Siddiki B, Ho JJ, Huang J, Byrd JC, Lau E, Yuan M, et al. Monoclonal antibody directed against colon cancer mucin has high specificity for malignancy. Int $\mathcal{F}$ Cancer 1993; 54:467-74.

149 Ikeda Y, Kuwano H, Baba K, Ikebe M, Matushima T, AdachiY, et al. Expression of sialyl-Tn antigen in normal squamous epithelium, dysplasia, and squamous cell carcinoma in the esophagus. Cancer Res 1993;53:1706-8.

150 Werther JL, Rivera-MacMurray S, Bruckner H, Tatematsu $\mathrm{M}$, Itzkowitz SH. Mucin-associated sialosyl-Tn antigen expression in gastric cancer correlates with an adverse outcome. Br f Cancer 1994;69:613-6.

151 Inoue $M$, Ton SM, Ogawa $H$, Tanizawa O. Expression of Tn and sialyl-Tn antigens in tumor tissues of the ovary. Am $\mathcal{7}$ Clin Pathol 1991;96:711-16.

152 Cho SH, Sahin A, Hortobagyi GN, Hittelman WN, Dhingra K. Sialyl-Tn antigen expression occurs early during human mammary carcinogenesis and is associated with high nuclear grade and aneuploidy. Cancer Res 1994; 54:6302-5.

153 Inoue $M$, Ogawa $H$, Tanizawa $O$, Kobayashi $Y$, Tsujimoto $M$, Tsujimura T. Immunodetection of sialyl-Tn antigen in normal, hyperplastic and cancerous tissues of the uterine endometrium. Virchows Arch A Pathol Anat Histoplathol 1991;418:157-62.

154 Kakeji Y, Maehara Y, Morita M, Matsukuma A, Furusawa M, Takahashi I, et al. Correlation between sialyl-Tn antigen and lymphatic metastasis in patients with Borrman type IV gastric carcinoma. Br $\mathcal{A}$ Cancer 1995;71:191-5.

155 Ogata S, Ho I, Chen A, Dubois D, Maklansky J, Singhal A, et al. Tumor-associated sialylated antigens are constitutively expressed in normal human colonic mucosa. Cancer Res 1995;55:1869-74.

156 Jass JR, Allison LM, Edgar S. Monoclonal antibody TKH2 to the cancer-associated epitope sialosyl-Tn shows crossreactivity with variants of normal colorectal goblet cel mucin. Pathology 1994;26:418-22.

157 Ogata S, Maimonis PJ, Itzkowitz SH. Mucin bearing the cancer-associated sialosyl-Tn antigen mediates inhibition of natural killer cell cytotoxicity. Cancer Res 1992; 52:4741-6.

158 Singhal A, Fohn M, Hakomori S. Induction of $\alpha-N$ acetylgalactosamine- $O$-serine/threonine (Tn) antigenmediated cellular immune response for active immunotherapy in mice. Cancer Res 1991;51:1406-11.

159 O'Boyle KP, Zamore R, Adluri S, Cohen A, Kemeny N, Welt $S$, et al. Immunization of colorectal cancer patients with modified ovine submaxillary gland mucin and adjuvants induces IgM and IgG antibodies to sialylated adjuvants induces IgM and IgG
Tn. Cancer Res 1992;52:5663-7.

160 MacLean GD, Reddish M, Koganty RR, Wong T, Gandhi $\mathrm{S}$, Smolenski $\mathrm{M}$, et al. Immunization of breast cancer patients using a synthetic sialyl-Tn glycoconjugate plus Detox adjuvant. Cancer Immunol Immunother 1993 36:215-22.

161 Miles DW, Happerfield LC, Smith P, Gillibrand R, Bobrow LG, Gregory WM, et al. Expression of sialyl-Tn predicts the effect of adjuvant chemotherapy in node-positive breast cancer. Br f Cancer 1994;70:1272-5. 